\title{
ON THE CONTEXT OF BENEVOLENCE: THE SIGNIFICANCE OF EMOTION IN MORAL PHILOSOPHY
}

Prasasti Pandit*

Department of Philosophy, West Bengal Education Service West Bengal, India

DOI: 10.7906/indecs.19.1.5

Regular article
Received: 10 October 2020. Accepted: 3 February 2021.

\section{ABSTRACT}

In this article, I argue that the principle of benevolence occupies a unique place in moral theory where duty and emotion both have equal importance, and moral philosophers generally are divided into two camps regarding the role of emotion in morality. Kant clarifies his position while introducing the deontic notion of benevolence. He only regards the moral value in which the duty of benevolence has been performed with 'good will'. Some defenders of Kant's ethics are Herman, McMurray, Meyers, and Tannenbaum who argue that acting purely based on duty is far more superior to acting from emotions. On the other hand, several contemporary theorists such as Bernard Williams, Blum, Oakley, Stocker, Stohr, Foot, Korsgaard, Hursthouse, and Sherman refute Kant's views towards emotion in the domain of morality. Following this Kantian and Non-Kantian debate, this article aims to explore the role of emotion and rationality in the moral context of benevolence.

\section{KEYWORD}

benevolence, emotion, duty, rationality, Kantian, non-Kantian

\section{CLASSIFICATION}

JEL: $\quad$ I12 


\section{INTRODUCTION}

Benevolence is regarded as a virtue of being disposed to act for the benefit of others in moral philosophy. Benevolence which holds significant moral value is sometimes regarded as moral emotion and sometimes as duty. Kant clarifies his position while introducing the deontic notion of benevolence. He differentiates between a naturally sympathetic person and a cold-hearted philanthropist and holds that, although both of them perform their duty of benevolence, Kant only regards the moral value in the latter case as there the duty of benevolence is performed purely for the purpose of duty. A naturally sympathetic person performs her duty based on her natural inclination to help others which gives her satisfaction. However, for Kant, such pathological emotions are situation-specific and subjective according to one's own personal preferences. On the contrary, a cold-hearted philanthropist who is not driven by sympathetic inclinations performs her duty of benevolence since it is her duty to do so. Such a cold-hearted philanthropist will stay calm and indifferent in any situation and perform her duty universally. Hence, Kant regards only duty-based benevolent actions as having moral value.

\section{KANTIAN AND NON-KANTIAN DEBATE}

Kant strongly rejects any emotional involvement within the domain of morality. He devalues any pathological and sensible feelings and denies them as motivations for moral actions. For instances, according to him, 'Sympathetic joy and sorrow are really sensuous feelings of a pleasure or pain at another's state of happiness or sadness' [1; p.456]. Modern Kantians like Barbara Herman, C. D. Meyers, Julie Tannenbaum, and W. Ashley McMurray defend Kant's view and forward his way of thinking regarding duty devoid of emotion in morality. Nevertheless, thinkers like Bernard Williams, Lawrence Blum, Karen Stohr, M. Baron and contemporary virtue ethicists such as Justine Oakley, M. Stocker, Christine Korsgaard, R. Hursthouse, Nancy Sherman reject Kant's degraded view on emotion and argue strongly for the enormous value of emotion in morality. Therefore, a detailed discussion on the role of emotion in morality in the context of benevolence is essential. I will develop and analyze their arguments in this article.

\section{HERMAN'S IMPARTIAL VIEW VS BLUM'S PARTIAL VIEW OF MORALITY AND EMOTION}

Barbara Herman [2] defends Kant's position on emotion in morality. According to her, Kant regards duty as the motive of all moral actions and discards emotions as they lead to the right action only by chance. Alike other nonmoral motives emotion leads to the right action only when it is aligned with the motive and circumstances of the action otherwise it will lead to the reverse of morality. Herman illustrates her point with the example of shopkeeper. It is a moral duty to treat every human being honestly as an end. A moral shopkeeper will return the proper change to an inexperienced customer since it is his moral duty. Again, a shopkeeper can do the same action not from duty but from a self-interest of profit for expanding his business. Although both actions are the same, there is a moral difference between a shopkeeper's dutiful action from his selfmotive of profit. In the former case, he treats all his customers equally as moral duty requires to do so. However, for the latter case he treats everyone equally but not as an end but as a means of his selfish purpose of business profit. Here the shopkeeper acts morally circumstantially due to fulfilling his self-interest. Here his motive of business profit controls his action, and so it is unreliable and contingent to act morally always since "while it is always morally correct to serve 
people honestly, acting from an interest in making a profit will require honest actions in only some circumstances-there may be times when honesty is not the best policy' [2; p.363]. Conversely, the motive of duty includes in itself the interest or good will of the rightness of the action. So, actions that are motivated from duty always necessarily include its rightness. This concern and interest of the agent always lead to the right action not by chance but due to the obvious relation between the duty-motivated actions and the rightness of the action. On the above instance the shopkeeper who is motivated by self-interest acts morally by chance but not in obvious manner, and it may also possible that he acts in nonmoral manner if it serves his selfinterest. However, the shopkeeper who is motivated from moral duty presupposes the rightness of his action since his motivation comes as a command of categorical imperative from the good will which is universal and absolute. Emotion cannot be the moral motive as it does not include the necessary interest of the rightness of moral action and the concern which will 'guarantee that the right action will be done' [2; p.363]. Hence emotion is conditional, contingent and unreliable. According to Herman, Kant rejects emotion as moral motive not only because it lacks the interest of the rightness of moral actions but also because emotion implies no moral interest in the part of the motive. Emotion-motivated-action leads to moral rightness luckily only when emotion is aligned with the motive and circumstances of the action. Hence, she concludes that Kant rejects emotion as moral motive not only because it has no moral interest in itself, but because it often leads us to immoral actions.

We may object that following Kantian view, if a person helps others only because duty requires to act on that manner, the person is overlooking the prime motive of this action which is the concern for other's well-being. In contrast when a person is concerned for others' well-being, she is motivated to help others from that concern to promote well-being for others. The categorical imperative of the duty of benevolence is derived from the good will. If the person who is doing the duty of benevolence only for duty's sake, she fails to realize the real moral value or the good will of the duty of benevolence and performs that duty without internalizing its moral worth. In the helping-other situation, one will treat the receiver as end in itself, if she has the concern or good will to promote the well-being of others. Absence of this concern implies that the person uses the receiver as a means to fulfill her duty requirements.

Herman replies that this objection raised from the error of viewing the motive (the duty) and end (the object of action) as reciprocal concepts [3]. The motive is what directs or moves a person to do certain actions, whereas, the end or object of an action is the state of affair which the person aims to bring about. However, these are not always reciprocal. The motive of the object is something that moves the agent into action for a certain object of interest. For example, suppose an object of action is buying my new jacket. Now this object of action may have different motives, such as a genuine requirement of a jacket which can save me from the cold or it can be the desire to show-off to some of my acquaintances or it can be just because the holiday sale is happening. My acts will be affected by these different motives and the meaning of the state of affairs which I bring about. Again, a different choice of actions can be prompted from the same motive based on agent's other interests and circumstances. So, it is necessary to include the full account of both motive and end in the domain of morality. According to Herman, the motive of duty is different from the motive of the object. A person can be motivated to help others from the duty of benevolence while she is emotionally concerned for the person's welfare which is the object of her action. She claims that emotionally motivated action has not any extra moral value which the critics claim for, writing, 
A compassionate person (one to whom it is a good that he is moved by feelings of compassion) does not act in order to be compassionate or to do the compassionate thing. His actions are expressions of his compassion. In a similar way, when Kant describes the actions of the moral person, they are presented as expressions of his "respect for duty". Being unable to help while acknowledging the claim of need, it will be natural to feel regret at being unable to satisfy the need [3; pp.374-375].

Another objection has been raised by Bernard Williams [4] that a person who is motivated to help others from emotion, will have the natural, immediate human gesture which comforts the recipients, whereas the person who helps others only to fulfill the requirement of moral principle is devoid of this natural human gesture. Williams regards this natural human gesture to help others as holding intrinsic moral value.

In response Herman nullifies this objection by arguing that Kantian morality of duty does not devalue the emotion-based helping action because Kant would emphasize that the agent who is motivated by emotion also acts permissibly but such emotion-based helping action is conditional in contrast with the unconditional duty of benevolence. Finally, for Herman [5] helping others is unconditional and universal only when it is guided by duty but it is conditional and temporary when helping others is guided by one's own emotion towards others since personal preferences affects the rightness of the impartial duty of helping others.

To the contrary of Herman's impartial view, Lawrence Blum [6] on one hand, rejects the Kantian impartial notion of morality and, on the other hand argues for the moral relevance and significance of altruistic emotions such as sympathy and compassion. These feelings emerge out of concern for others and are directed to the 'weal and woe' of others and thus play their particular role in our understanding of moral life and action. These altruistic emotions themselves can provide the motive of good actions and can provide the appropriate response of the beneficent act to others who are in need and suffering. According to Blum, the appropriate response of the beneficent act for others can be motivated either by such altruistic emotions or by Kantian notion of duty. These altruistic emotions which express their emotion to recipients hold intrinsic moral worth not only because these emotions are the motivation for good action, but also due to the concern these emotions hold and express for the good of others. For Blum, these altruistic emotions build the central aspects of our moral character and thus such altruistic emotions become the proper objects of moral assessments and of moral striving. The Kantian position denies the significance and moral worth of these altruistic emotions and hence somehow distorts the moral character of pure duty. The Kantian position identifies morality with duty and obligation and finds the moral worth of action within an agent's unconditional obedience to rationality and to the universal principle of duty based on rationality. However, Blum establishes friendship as a representation of the moral character based on the altruistic emotions and recognizes friendship as the locus of moral worth and moral actions. Here, he distinguishes the altruistic emotions from mere non-moral inclination. Friendship, for him, is neither constituted with mere non-moral inclinations nor from the Kantian universal notion of duty, but from the moral emotion which emerges from the concern for others and directed to the weal and woe of others. By rejecting the Kantian notion of emotions, Blum argues that altruistic emotions are not necessarily self-interested or unreliable. Altruistic emotions should not be seen as irrational or non-rational motives since these are also capable of satisfying the fundamental requirements of morality. The moral goodness of the altruistic emotion for one's friend consists in the selfless act one does for one's friend's sake. The moral worth of such actions consists within the willingness and readiness to help one's friend for the friend's own sake. These selfless other regarding 
altruistic acts for one's friend satisfy the fundamental requirement of morality and absence of this selfless willingness and concern for one's friend is considered as moral failure. Blum regards one's true genuine selfless concern for one's friend and the selfless willingness to help friends for their own good as one's moral excellence. The moral requirements in Kantian ethics are only limited to the criteria of universality and impartiality. Nevertheless, the requirements of universality and impartiality are relevant for certain limited contexts of morality, we cannot reduce the whole concept of morality in terms of duty or obligation or agent's unconditional obedience to them. In the contrast to Kant's impartial view towards every human being, Blum accepts the special concern which we pose for our family and friends. In his own words, 'In friendship one desires and acts for the good of the friend, not simply because he is another human being but precisely because he is one's friend'[6; p.44]. Blum argues that the special concern and duty which require selfless concern and willingness to help one's family and friend for their own sake is the foremost obligation of morality and failure of which is morally blamable and not accepted. For him, altruistic emotions belong to the different discourse of moral worth and that is why they are not limited within the direct control of rationality. So, unlike Kant's emotion-less moral theory, Blum argues that it is morally necessary to have altruistic emotions.

I also believe that as a human being we are not devoid of emotions, rather as a moral human being we should acquire such altruistic emotions which motivate us to do benevolent acts for others' sake. Human beings should have the special concern for their family, friends and loved ones. In the cases of benevolent actions, I believe that one first moves from her altruistic dispositions to help others and that these altruistic dispositions serve the motive of the duty of benevolence. For example, when I heard that my friend had an accident, I immediately felt concern, and due to this concern for my friend's well-being, I wanted to do something for her well-being. So, this moral concern for the well-being of others serves as a motivation of benevolent act. However, unlike Blum, I believe in some emergency situations one feels that concern of well-being for strangers as well. Such concern should be present within every moral being, and the absence of this moral concern can be regarded as a moral deficiency. For example, when I see a stranger fall down from a bus and got injured, I feel that immediate concern for the person's wellbeing and act benevolently for the person's sake. These altruistic emotions which serve the motive of benevolent duty for others are essential for one to be moral. Moreover, even when we cannot actively act benevolently due to our spatial and other material limitations, we should dispose the altruistic concern and emotions for our farthest neighbor who are in adversity. For example, whenever we hear the miserable conditions of the babies of Syria we immediately feel sorry for them and pose moral benevolent concern for their well-being. This altruistic emotion for others' welfare is the core of morality since it is imbued with the very essence of humanity.

\section{KANTIAN VIEW VS VIRTUE ETHICISTS' VIEW ON EMOTION}

Alike Blum, M. Stocker [7] also argues that the problem with the modern rule-based theory is that it considers the same reason as motive for morally right actions in every context, despite that, such universal reason or rule-based motive should not be considered as our motive for morally right actions in certain contexts like benevolence. If an agent helps someone coldheartedly simply for the sake of duty and devoid of any compassionate feelings, then that person's attitude appears that she is treating the other person externally which devalues the other person's autonomous moral worth. Stocker considers that such a person is morally deficient, and her treatment towards her beneficiary goes against Kant's second maxim which commands us to never treat a rational human being only as a mean since rationality implies that every human 
being is an end-in-itself. Treating other people as ends-in-themselves evokes the responsibility to treat those persons with proper respect. To treat other persons with proper respect, Stocker emphasizes those human gestures which include love and friendship. The absence of these proper emotional responses makes a person devoid of these moral virtues. A cold-hearted benefactor devoid of these altruistic emotions following Kantian theory treats other people instrumentally and not as ends-in-themselves. He illustrates this point with an example where a person visits his friend in the hospital only out of duty and devoid of any feelings of love, sympathy and concern. According to Stocker, there is something wrong with his action. It seems that the person may be motivated from some wrong purpose as there is a genuine moral deficiency in his action. The action is morally deficient not because it is wrong since here the person performs his duty properly which is right, however, there is something lacking in his action that is the virtue of love. A genuine friend should visit his injured friend out of love, sympathy, and concern rather than simply with a cold-heart which is solely motivated from duty and devoid of any such feelings. The person devoid of any such feelings lacks moral value and merit and so, in such cases, it is wrong to regard duty as the only motive of morality.

Following Kantianism, there is nothing wrong with the person who visits his friend in the hospital as she perfectly performs her duty. There is nothing more to claim for her morality. The problem with Kantianism is that here duty is regarded as the one and the only motive for morality, however, Stocker objects that it is morally devaluing in such above-mentioned cases where the agent is only motivated from duty alone. The person lacks the emotional motive of sympathy, love, and concern which she should have for her friend, absence of which affects the moral value regardless of whatever she does for her friend by only motivated from duty alone. Friendship evokes some expectations which are beyond the notion of rule-based stringency of duty and so we cannot explain this within the limits of the rule-based deontic notion of duty. So, Stocker rejects the exclusive claim of reason-based deontology where duty is generally regarded as the sole motivation for all situations and concludes that sympathetic inclinations for a friend should be regarded as the moral motivation specifically in the context of benevolence.

Again, for Philippa Foot [8], benevolent action holds 'positive moral worth.' An action which holds a 'positive moral worth' 'is action that is in accordance with virtue and also displays a virtue that has moral worth' [8; p.174]. Foot finds that since benevolence or charity is a virtue of attachment and sympathy, such a virtue makes it easier to attach one person with the other person. For example, a sympathetic person tends to act for others since they can sympathize with the miserable condition of other people. It makes the person more easily attached to other people and disposes someone to act benevolently for others. Following Foot, the person who acquires the moral virtue of sympathy and compassion holds moral worth since these virtues not only make easier to perform the duty of benevolence but increases the moral value of such benevolent actions. Now, Kant's philanthropist who is devoid of any such emotions but performs her duty based on the sense of duty is not to be undervalued, however, the person who most shows virtue to others while performing the duty, the most moral worth this person holds by showing positive emotion to others as a key part of virtue. As charity is both the virtue of attachment as well as action, when sympathy is a key part of the virtue, it is easier to act in accord with the duty of charity. According to Foot, a deeper analysis on Kant's dutiful philanthropist reveals that that person who feels no sympathy and finds no happiness by seeing the good of others as his mind is full of despair and sorrow of his own, and so, she adds that 'this is the kind of circumstance that increases the virtue that is needed if a man is to act well' [8; p.174]. However, for me, the person who despite of his mind full of sorrow for his own adversity, performs the duty of benevolence 
for his duty's sake without any sympathetic or compassionate attachment with other beings, fails to attach the morally required connection to the person he is showing kindness. He is not showing the morally required gesture of kindness towards the beneficiaries and hence, he is not treating those persons as ends-in-themselves, rather he is using them as means only to perform his own duty for his duty's sake. To be precise, the duty of benevolence occupies a different domain of morality where performing the mere duty itself does not hold the moral worth of these actions. To be moral, these actions require the virtue of sympathy, compassion, concern of well-being, and love for others, not only because such virtues make it easier to perform the duty of benevolence, but the absence of these virtues nullifies the moral worth of these duty-based actions.

On the contrary, Kant argues that the person who is by nature cold and strong and who is not easily affected by any distress of life can imagine the same for others. And if one's emotionally controlled nature does not affect her duty, there is nothing to be morally deficient about her. Moreover, he mentions that human beings with limited rationality and embodied emotion often struggle with conflicting inclinations, however, it will not happen with a fully rational being who is always guided by her reason.

However, this is an inadequate approach of Kant since a normal human being cannot cut all her emotions and inclinations from her life. Human beings due to their very humanness must combine reason and emotion. Only rationality or only emotion cannot build a person as human. So, we need these both; and, as I have argued before, altruistic emotions are necessary for a moral being. According to Christine M Korsgaard [9] and Rosalind Hursthouse [10], while performing benevolence, the Kantian moral agent exhibits mere continence or enkrateia rather than full virtue or arete. According to Hursthouse, the Aristotelian distinction, enkrateia holds the higher moral worth rather than akratia or incontinence. An akratic person can be driven by emotional feelings or pathos which goes against her rational choice. Although like the akratic, an enkratic person experiences the dilemma between reason and such emotional feelings which are contrary to reason, unlike the akratic, the person acts in accordance with reason. But the deficiency of an enkratic person is that she experiences passions that conflict with her rational choices. Now, a fully virtuous person who develops the highest moral virtue or arete does not face the dilemma within rational and irrational emotions. However, Kant fails to recognize this Aristotelian weighting of the enkrateia/arete distinction, and so he holds a partial view for emotion. He is concerned about the misleading nature of emotion which may misdirect a person from morality. However, from a virtue perspective, only a continent person always struggles with rival inclinations while performing her duty based on obligation, whereas, a fully virtuous person performs her action easily without doing any struggle against rival emotions since a virtuous person always chooses the right action. It can be assumed that a cold-hearted benefactor can perform her duty with grudge and dissatisfaction while struggling with rival inclinations. Aristotle makes this distinction between enkretia and akrete and claims that mere continence follows moral deficiency within moral agents. I also believe that Kant is only concerned about the misleading features of emotion. Firstly, emotions, unless conjoined with good will, may misdirect us from doing the right duty. Again, excessive emotional outburst leads to heteronomy which subdues the prime obligation of performing any duty. So, it seems that Kant accepts a continent moral being who can perform her duty properly only due to the obligation of duty's sake despite her cold-heartedness or lack of moral impulses.

Furthermore, Justin Oakley [11] argues that in these cases of helping others, the agent is not only motivated from mere compassionate impulses, but the person also cognitively recognizes another 
person's distress which motivates him to help the person. Consequently, emotions can have such cognitive dimensions that have worth by themselves to motivate some actions. Thus, emotional capriciousness may not be a sign of the inadequacy of emotions themselves as moral motives, so much as an indication of a kind of moral failing in the particular person whose emotions are typically capricious' $[11 ; \mathrm{p} .445]$. He argues that, while we are performing the beneficent actions, our object should be to help others rather than only fulfilling the moral duty as helping others from altruistic emotions which include unconditional attachment towards the needy person and which are morally required in these cases rather than merely performing beneficent actions only from duty. He emphasizes that a sympathetic person is more capable of performing the beneficent act than the person who is motivated purely from duty since "having sympathy or compassion for another is often necessary to gaining a proper understanding of what actually needs to be done in order to help her" [11; p.454].

Bernard Williams also argues against Kant's impartial moral position which abstracts the particularity of individual people by categorical imperative and overlooks a person's personal standpoint. This position often leads to confrontation between the moral and non-moral point of view in the context of intimate attachments. He elaborates his view by an instance. Suppose a man is in the middle of a position where he can only save his wife or a stranger at the same time. Here, according to Williams, it is not only morally permissible for him to save his wife, but it will be morally deficient if he does it only out of duty's sake. According to him, if he saves his wife because it is consistent with moral principles, then it 'provides the agent with one thought too many: it might been hoped by some (for instance, by his wife) that his motivating thought, fully spelled out, would be the thought that it was his wife, not that it was his wife and that in situations of this kind it is permissible to save one's wife' [4; p.18]. His action which is resulted out of duty and not out of love makes the person devoid of moral virtues which underlies the necessary requirements to be a human. The Kantian position which acts solely from duty alone fails to express the deep attachment and love an individual holds towards his/her intimate relations.

Marcia Baron [12] extends Williams's illustration where a person finds himself in the middle of a critically injured stranger with his mildly injured wife at the same time with the dilemmatic position where he can only save one of them. Here Baron points out that, in this situation it will be morally right for the person to assist the critically injured stranger rather comforting his mildly injured wife, however, she points out that, something will be morally deficient for the person if he easily leaves his wife to assist the stranger without showing her any genuine sympathy or compassionate concern.

According to her, Kant is misjudged in his Doctrine of Virtue [1]. For Kant, the moral character of an individual flourishes from the moral worth of good will which is committed to performing what moral law requires and this should be the primary motive of duty which is directly actionguided. Again, duty operates as a secondary motive that directs agent towards something else rather than the main duty, and these motives presuppose some emotional motivations of moral duty, such as pleasing someone presupposes love and care or helping someone presupposes sympathetic inclination. So, this secondary motive has an important role in determining morally acceptable inclinations. Baron, following Kant, accepts that moral actions are motivated from duty, but for her, Kant does not deny the secondary role of emotion as a motivator for moral actions.

Karen Stohr [13] replies that, although Baron makes the right claim, it is problematic for Kantians to clarify why without required moral feelings an action is regarded as morally deficient. Baron identifies the lack of moral deficiency in the Kantian position where the man is 
perfectly morally right, however, he lacks sympathy and fails to motivate from care which makes him the cold-hearted benefactor. In this context of intimate attachment, the man's sympathetic and loving heart for his wife motivates him to comfort his loved ones whereas his compassion for the poor stranger motivates his sense of duty to help the stranger who needs immediate assistance. According to Stohr, it is intuitively true that sympathetic feelings are obvious for beneficent actions. To her, feelings are essential for human good and for developing virtues. No actions or persons will be fully moral without the necessary moral feelings. Stohr points out that, Kantianism claims duty as the sufficient reason for motivating moral actions, whereas they do not regard the necessity of sympathetic emotions for motivating moral actions. He illustrates this point by an example of a boy named Jim who born and grown up in a racist environment with a parental lesson that black people are not competent and not up to his level and so they are the subject of distrust. Jim manages to overcome this ignorant parental lesson by realizing that these attitudes are morally wrong, and he mingles with black people freely and also helps them in their need. However, he cannot help but secretly finds racist jokes as funny. Although he immediately responds to a joke-teller with appropriate moral indignation, he cannot help himself to be amused with these racist jokes. According to Kantian standpoint, he is doing everything to fulfill his duty by treating black people as ends and cultivate sympathies which help him to perform his duty. But the matter of fact is that Jim can be a morally better person if he does not find those racists jokes funny as it is a moral failure for his character to find those jokes funny. However, Kantians can never point out this moral failing as according to them, Jim has done everything with his good will and if something is beyond control for a person, he is not obligated to do so. Similarly, if acquiring some particular feelings is impossible for a person, lack of it, is not a moral deficiency. However, Jim can try not to find the racist jokes funny by developing himself towards a more morally virtuous person. Consequently, from the standpoint of virtue ethics, actions fail to be virtuous if the agent performs them in absence of appropriate moral feelings or attitudes. So, according to virtue ethicists, cold-hearted benefactors are morally deficient since they fail to feel sympathy for those whom they help.

The place of emotion is different in Kantian ethics and in virtue ethics. According to Kantianism, sympathetic inclinations are helpful while performing a duty, however, one who is thoroughly committed to duty, may not require any such inclinations to motivate herself to perform her duty. Both Kantian ethics and virtue ethics consider a place for emotion, but they differ in their standpoints. Sympathetic feelings, for Kant, are primarily instrumental as they help to motivate duty when human beings due to their finite, imperfect capabilities fail to act fully rationally. For Kant, cultivating such feelings is helpful to perform other duties as nature has 'implanted in us to do what the representation of duty alone would not accomplish' [13; p.195]. Again, Kant claims that such sympathetic feelings or inclinations are not required for the fully rational being who is completely imbued with holy rational will. On the contrary, the fact there is no such conception of pure holy will in virtue ethics, however, virtue theorists consider only human beings who have emotions and inclinations along with rationality. Here, emotions are valuable in morality but in a different way from Kantianism. Stohr concludes that morality requires that the generosity of the benefactor will not only be motivated from the rightness of the action, but that it should be motivated from the appropriate emotions such as love, care and concern which the Kantian agent lacks and this cold-hearted Kantian agent without these feelings represents moral deficiency while performing all of her beneficent acts.

On the contrary, Julie Tannenbaum [14] defends the Kantian position by distinguishing between 
an action's manners from its motive, i.e., the reason of action. Her aim is to establish how emotion can be present in the action's manner without being its motive. To establish her standpoint, she demonstrates how compassion can comfort other-beings without being motivation. She formulates the critics' arguments as,

1. Sometimes one is morally required to express an emotion.

2. The expression of an emotion must be done from an emotional motive.

3. Thus, the expression of an emotion cannot be done from the motive of duty alone.

4. Thus, sometimes one cannot do what is morally required from the motive of duty alone [14; pp.322-323].

Summarily, critics argue that compassionate actions are incompatible with the motive of duty and so, compassionate actions should be motivated from compassion. In response, many Kantians, including Herman, Baron, Sherman, do not deny the mutual exclusiveness of duty and compassion. Herman accepts two different roles of duty where the primary role is to motivate a person in acting which is morally required and to limit such actions which are morally impermissible. Hence, in such compassionate actions, Herman and the other two thinkers consider duty as a limiting condition and regard emotion as an important motivational objective for such actions. For example, when a person helps a stranger by being motivated from one's compassionate emotions towards others, she does so since helping from compassion is not morally forbidden. To be precise, when compassion leads to help others it is morally permissible. Hence, here she acts from two motives, compassion and the limiting motive of duty which controls and directs the emotionally driven actions into the morally right path. However, if we accept emotion as the primary motive and duty as a limiting condition, another problem arises regarding the goodness of such emotionallymotivated actions. For Kant only those actions hold moral worth or goodness which are motivated from duty alone. Tannenbaum claims that previous defenders of Kant having failed to notice that emotions can only shape an action's manner, duty is the only moral motivation. Hence, there is no point in arguing about the moral goodness of such actions. She makes the distinction between the manner of action and with the motive of the action, writing: 'the manner of an action is how it is done, and the motive delineates the agent's reason for acting' [14; p.324]. By demonstrating different examples, her aim is to establish here that, 'how an emotion can influence the manner of an action without also serving as the motive' [14; p.325]. For example, she mentions the profession of nursing where nurses might act compassionately out of their need for pay raises. This financial motive is not incompatible with or mutually exclusive from compassionate actions. Again, when someone assists her weak grandmother, one must be extra careful and concern regarding 'not to bruise on her tender arm' and not 'to humiliate her' by any means. So, 'helping in such way' is morally required, and helping her for this reason implies helping from the motive of duty. Here my expression of helping her involves genuine compassionate passion.

Critics may argue that helping the grandmother is motivated from compassion only rather than motivated by duty. Tannenbaum serves two replies here. Firstly, if we act only following the reason that I will not bruise on my grandmother's arm as it will cause her pain, both the motive of acting from duty and the motive of acting from compassion require nothing more than considering this fact of not bruising her arm. Hence, if ' $I$ act from one motive, this motive can be appropriately called duty, and so I can act with compassion from duty alone' [14; p.330]. Secondly, there is always a reason for every reasonable motive. Here, helping my grandmother with compassion from the motive of duty is grounded with the reason that helping her in such a way will avoid unnecessary pain as avoiding unnecessary pain is morally required. On the 
contrary, helping my grandmother with compassion from the motive of compassion provides a reason for helping in such way that I will avoid unnecessary pain to her. So, my reason for helping my grandmother includes avoiding unnecessary pain which, Kant would claim, a person can do compassionately by being motivated from duty alone. Again, one may argue that acting from genuine compassion implies that the agent must feel compassionate towards other beings, but Kantians do not have such feelings in their conception of duty, although morality requires such feeling. Tannenbaum and many other Kantians claim that 'ought implies can' and if morality requires such feelings, we must develop compassionate feelings towards the recipients while acting compassion from duty. So, it is blamable if one fails to develop such morally required feelings as Kant himself also argues for developing such sympathetic feelings to be a morally better person. One can strive to be a sympathetic person as well as can act sympathetically by expressing those feelings in the right manner.

Thus, Tannenbaum provides the justification of developing emotional faculties within a Kantian perspective where the moral status of action depends in part of emotional manifestation. However, she holds that, 'since some emotional manners may be morally required while others are morally forbidden, it is important that an agent work towards developing the right kind of emotional dispositions' [14; p.335,]. Thus, Tannenbaum establishes that, one can act with compassion from duty as it is morally required, and duty-based motivation does not undermine one's compassionate capability of acting in such manner. Hence, she concludes by establishing 'the possibility of acting compassionately from duty alone' $[14 ; \mathrm{p} .336]$ and simultaneously replies to the critic by showing that, 'acting from duty precludes acting in emotional ways that we value' [14; p.336].

Against this view, C.D. Meyers [15] defends the Kantian position strongly by claiming that, there is nothing wrong or morally deficient to act from duty alone rather people should be motivated always from duty alone. According to him, the person who visits his friend motivated from duty and not from love or sympathy 'is self-absorbed and reveling in her own moral superiority' [15; p.236]. He assumes that the sick person may be admitted to the hospital due to his own fault of reckless behavior, despite repeated warnings from the reluctant visitor. In such a situation, we cannot blame him to feel less sympathy, rather praise him as he controls his temptation and visits his friend in the hospital for the sake of his duty towards his friend. Hence, our intuitions can change due to different background details, so we can disapprove of those details rather than disapprove of merely acting from duty. Critics argue such a person with a lack of sympathetic inclination is not morally blamable but morally deficient, however, Meyers finds such claim confusing as if he is not morally blamable due to his lack of sympathetic inclination, so he is not morally deficient. This kind of person may ignore his wife to help a stranger in Baron's example. We can say that, he is not a good husband, but we cannot claim that he is morally deficient. Hence, for Meyers critics' objections are misdirected as 'objections to acting from duty alone may be based on a confusion between moral virtues and other socially desirable character traits that have no moral' [15; p.237].

Moreover, Meyers recognizes cold-heartedness as a virtue rather than as a moral deficiency. Sympathetic feelings, unlike moral sense of duty, can lead an agent to do something wrong or something which may fail to do what should be morally right. So, for him, a sense of duty is always morally superior to love and sympathetic feelings, consequently, lack of these feelings or cold-heartedness can be recognized as a desirable character trait than as a vice. He illustrates this notion with an example that we generally feel moved by observing the images of starving people in television. But sympathetic people with their sensitive feelings may not bear the sight and 
change the channel, whereas, cold-hearted philanthropist can do his duty by donating for the sufferers. Similarly, social workers can maintain distance with their clients to do their work properly, otherwise their sight of distress may deeply affect them emotionally that they cannot perform their duty properly which is actually required for them in those situations rather than simply showing some sympathy. People can avoid their actual duty by showing mere sympathetic gesture. These people are less virtuous with less moral worth in general as they are not disposed to do the right thing.

Kant distinguishes between practical love which lies in our will and pathological love. Pathological love cannot be commanded, whereas, practical love of doing benevolence from duty comes as a command of will even where inclination of practical love is not intended. Following Kant, Meyers also distinguishes between two types of sympathy. Pathological sympathy, for him, arises from pain by perceiving others' miserable condition. Yet, practical sympathy directs the agent to do something which alleviates the other person's suffering; however, it might not include any sympathetic emotions. Consequently, failure to help those in need indicates a lack of practical sympathy rather than a lack of a pathological sympathy.

A person guided with emotions often is inclined to do what is morally wrong, whereas, a cold-hearted benefactor is always guided by the sense of duty, and capable of avoiding such emotional misguidance of pathological love and sympathy. So, a cold-hearted benefactor is virtually also a better person than an emotionally driven sympathetic benefactor. Here, the benefactor is cold-hearted, since he is motivated by his sense of duty which is morally more desirable, rather than by mere emotional feelings of love and care. The above instance is a case of justice for Meyers where a man chooses to help a severely injured stranger than his mildly injured, beloved wife. 'The issue here is the distribution of a limited resource - namely his own ability to render immediate assistance. Fairness dictates that, in life-or-death situations like this one, we should administer help to those who need it most- even if that means forsaking a mildly injured loved one to help a critically injured stranger' [15; p.240]. Similarly, the duty of practical love or benevolence often conflicts with the feelings of pathological love, such as a king faces dilemma while punishing his rude and vicious son to protect his countrymen. None can blame the king if he performs justice by punishing his son. Here he overcomes his pathological sympathetic feelings for his practical love for duty. Thus, cold-hearted persons are morally better than emotionally driven persons as they are always guided by the sense of duty which 'unlike feelings, cannot lead someone to do what she knows is wrong or fail to do what she knows she ought' $[15 ; \mathrm{p} .241]$. The cold-hearted benefactor is more virtuous than a sympathetic benefactor as she always guides with the sense of duty and is able to absorb her emotions which might create a problem for performing her duty and often could have misguided her in doing something wrong. Hence, Meyers concludes that we should cultivate and practice practical sympathy, and it is this kind of sympathy that gives agents and their actions moral worth.

McMurray [16], another defender of Kantian notion of duty, recognizes that Stohr's position can be understood by following the impartial standpoint of Nagel and the Aristotelian thinkers who differentiate between "doing good" and "living well". To achieve a good life duty is not sufficient, one needs to develop one's sympathetic feelings for others and neither duty alone nor good will alone are sufficient to be moral. Following this view, Stohr claims the cold-hearted benefactor is a morally deficient person. However, McMurray replies that there is no such simple consistency between the right thing and good life as doing right often requires a significant sacrifice from the good life. Nagel [17] from his impartial standpoint of morality claims that, as 
all people are end-in-themselves, we cannot ignore their claim simply because they do not contribute good in our life. So, there is a genuine conflict between moral life and the good life in Aristotelian doctrine. It seems that there is a connection between moral life and good life, however, they are not dependent upon or implied by each other. Kant recognizes these two as separate and independent from each other as there are many who deserve the good life but are unfortunately deprived. However, rational human beings by their own nature aim to obtain the highest good, consequently, the absence of this good seems to be inconsistent with one's human nature. Similarly, this problem also occurs with the case of Stohr's cold-hearted benefactor. The cold-hearted benefactor seems morally deficient not because she fails to act morally but because she fails to contribute to the highest good which is consistent with human nature. Beneficent actions following general human nature require sympathetic feeling to achieve the highest good of happiness, and absence of such feeling is inconsistent with our natural sympathetic bond of humanity. However, Stohr has argued that a fully moral action should be done from sympathetic feelings and a fully moral person should have these feelings and not just try to obtain them. According to McMurray, morality only concerns what individuals are capable of doing. Since people cannot control the spontaneity of emotions, a lack of sympathetic feelings cannot be objected to as a moral deficiency. He recognizes this lack of feeling as a human deficiency. Since the highest good is every rational human being's objective end and sympathetic feelings are needed to achieve that end, absence of such feelings is to be regarded as a genuine human deficiency but not as moral deficiency. Moreover, since sympathetic feelings are essential to achieve the highest good, these are regarded as good-in-themselves. But Kant limits the relation of the feelings with morality and adopts only their instrumental value. However, it is inaccurate to accept their instrumental value in general as sympathetic feelings are essential to achieve the highest good and regarded as the objective end for every individual. On the one hand, Stohr, following the Aristotelian view, recognizes that the absence of these feelings is morally deficient; on the other hand, McMurray following Kantian notion of highest good recognizes that the absence of those feelings within individuals is a human deficiency.

Another view comes from Nancy Sherman [18] who tries to conjoin Aristotelian virtue ethics and Kant's deontology and establishes the role of emotion as a necessary condition to motivate an agent towards duty. She argues that, although Kant is aware that emotion may drive towards heteronomy, he accepts the fact that human beings who are partly rational and partly embodied with emotion can face the continuous turmoil between these two. So, Kant finds it is necessary to avoid the conflicting desires while performing moral action since such conflicting desires will affect the autonomy of the person. However, finite beings with limited rational capabilities often fail to be motivated from duty alone. For this reason, Kant introduces the concept of prudence in his Doctrine of Virtue where he accepts the fact that the good cheer or pleasure has a supporting motivational role for performing duty. Kant claims such emotions or inclinations are practical and not pathological. One should try to cultivate such practical emotions and inclinations which can be regarded as a duty itself as these emotions can help to accomplish what a sense of duty alone may not fulfill. However, Kant is aware of these accidental facts that natural pathological emotions often coincide with moral law. Kant distinguishes these emotions from the practical emotion of duty which comes as a reverence for the moral law and motivates human beings to do the right actions. Actions that are motivated from this moral emotion are always accorded with the rightness of moral law as here people are motivated to perform duty not only on the basis of their ultimate aim of duty but also on the basis of avoiding the limiting conditions on the expression of these emotions. 
Unlike fully rational beings, all humans who are embodied with partly reason and partly emotion often fail to be motivated from duty alone. Here the practical reverence for the command of moral law motivates those persons both valiantly and cheerfully. So, it is essential to cultivate such emotions and inclinations which harmonize with the moral law and develop virtue as well.

\section{CRITICAL EVALUATION}

Throughout the detailed discussion, we have observed that emotion has an undeniable role in the context of benevolence. Empathy and sympathetic emotions play a crucial role in developing the virtue of benevolence. We can illustrate this point by analyzing that famous example of Bernard Williams. As I have mentioned above, Williams gives an illustration where a person is stuck in the dilemma of helping his mildly injured wife or a severely injured stranger. The person usually holds a special concern and sympathy for his wife along with the special duty of a husband towards his wife. However, as a rational human being he also holds a general concern and duty towards every rational individual, and this rationality raises the duty of benevolence within the person for the severely injured stranger. If the person only has concern for his wife and ignores the severely injured stranger, he fails to perform his rational humanitarian duty towards the others, and so, he is morally blamable. Again, if he totally ignores his wife's injury and runs to help the stranger, he fails to perform his special duty as a husband towards his wife as well as a humanitarian duty towards others and so he is also morally blamable. So, he needs a balance between these two people according to the requirements of the situation. Here, as the stranger is severely injured, he needs to pay more concern towards him and should act to arrange the immediate help. However, it does not imply that he overlooks his minutely injured wife. He should sympathetically help his wife before running to help the stranger.

For me, sympathetic emotions and reason both are the important factors for performing the duty of benevolence. Often emotion may affect a sympathetic person so deeply that one may not able to perform her duty properly. In the above situation if the person becomes emotionally affected by the sight of accident and the injury of his wife or of that severely injured stranger, he cannot able to perform his duty. He may have so much emotionally engrossed that he starts panicking and even may break into tears. The situation will be even worse if the person faces a nervous breakdown or serious panic attack as he becomes so much emotionally bestraught by the injured people. Such an emotionally driven person cannot handle these emergency situations. However, in our daily lives, we often find ourselves within such emergencies and dilemmas where sympathetic outcomes are essential but not sufficient. In the above-mentioned emergency situation where the husband hypothetically is the only non-injured person and in proper physical condition should act fast to rescue others. He should call the ambulance for the immediate medical help of the injured people and also run to ask help from the localities. Hence, besides his special sympathetic concern for his wife and general concern for the stranger, as a rational individual the person should perform his required responsibilities. So, here we need a proper balance of both emotion and reason. Reason can control one's emotional outburst and helps to focus oneself to perform one's duty. In general, morality requires actually both emotion and reason. For me, the duty of benevolence comes as a moral ought from our core of humanity due to our moral, sympathetic concern for other beings.

Again, only reason-based duty lacks the required emotional sophistication, absence of which may show disrespect to the person for whom we perform our duty of benevolence since the moral virtue of benevolence presupposes genuine empathy and concern for other-beings. I want to 
justify this point by analyzing Stocker's example where a person visits his sick friend in the hospital. Here Stocker argues that the person who comes to visit his friend should be sympathetic and pose genuine concern for his friend otherwise his behavior will be morally deficient. Generally, we all have that special love and concern towards our close ones; and when our loved ones are in danger the duty of benevolence arises from that love and sympathetic concern we have towards them. Hence, absence of this concern is definitely moral deficiency. These are the most important moral virtues which one should develop for all. Now, a deficiency of these primary virtues towards one's close relative or friend never goes along with one's moral behavior. Only duty for duty's sake is the necessary condition but not the sufficient one. It also requires the moral concern and empathy for other beings for the successful application of our duty. If the person visits his friend only for duty's sake, the lack of concern and sympathy affects his sick friend and consequently the friend feels uncomfortable, neglected and becomes hurt. If someone lacks this moral concern, the motive behind his dutiful action raises a question. It's not only the dutiful visit for its duty's sake but the genuine concern and sympathy for a sick friend should be the motive of this visit. These emotions spring naturally from our genuine humanitarian concern for other-beings and love for humanity in general. So, these emotions hold equal moral worth along with reason to motivate one to help others. On the contrary, Meyers argues that the friend who is in hospital may be paying the penalty for his own heedless lifestyle and despite of repeated cautions he continues his rash driving and now he is suffering the consequences of his own reckless behavior. The person may be angry at his friend for this and so he is less sympathetic, but he comes to visit him in the hospital for the sake of duty. Again, despite of his friend's calloused behavior, there should be a genuine concern for his friend as a motivator behind his dutiful visit in the hospital; without this concern and sympathy it can be assumed that his motivation is something else but definitely not moral.

We can justify this point by following Kant. Since every person, being an end-in-itself, is worth their own moral value, we have the moral responsibility to respect every person and her dignity and never let anyone feel degraded or disrespected by our behavior towards them. Now, while performing the duty of benevolence we are directed to some actions which will help the recipients who are in adversity, danger or in some position from where we hypothetically stay in a better position. So, it is our duty not to make the person feel disrespected or uncomfortable as we provide aid. Sympathetic emotions are essentially associated with the duty of benevolence since it never makes the beneficiaries feel degraded or uncomfortable; moreover, it provides them emotional comfort which is equally required while performing the duty of benevolence in that adverse situation. Sympathetic emotions and the duty of benevolence complement each other. And it is our moral duty to love all that develops the notion of universal benevolence. We require a proper balance of both reason and emotion while performing these actions. No doubt, duty is a very complex concept. Generally, individuals are first moved by their empathetic feelings towards other beings. Such empathetic emotions for others create the obligation to do some benevolent actions which alleviate the sufferers of their pain. The whole emotional process serves as the motivation to perform benevolent actions. Gradually, our repetitive, similar actions in every similar situation develop the concept of duty when we help others purely from the sense of duty, internalizing the virtue of empathetic feelings from our moral humanitarian concern for others.

So, I prescribe a new version of benevolence which has the proper balance of reason and emotion and which arises from the very root of our humanitarian essence. Humanity is in itself is the embodied combination of both reason and emotion. The compulsion of benevolence arises from one's own deeply rooted humanitarian nature. Humans strive to be morally benevolent from in- 
side, and this version of benevolence believes in this inward reformation of humans by appealing to its inner humanitarian root. The disposition of benevolence unites other beings inwardly by touching other human's heart through its intrinsic nature, and it develops a person towards a morally better human being. The disposition of benevolence is stronger since it arises from the very essence of humanity, and also this disposition transcends an individual from one's own selfego towards others and gets into other human's heart through its humanitarian appeal.

\section{REFERENCES}

[1] Kant, I.; Paton. H.J. and Greogor, M.J., eds.: Doctrine of Virtue.

Harper \& Row, New York, 1964,

[2] Herman, B.: On the Value of Acting from the Motive of Duty.

The Philosophical Review 90(3), 359-382, 1981,

http://dx.doi.org/10.2307/2184978,

[3] Herman, B.: Rules, Motives, and Helping Actions.

Philosophical Studies 45(3), 369-377, 1984,

http://dx.doi.org/10.1007/BF00355444,

[4] Williams, B.: Persons, character and morality.

In: Moral luck: Philosophical Papers 1973-1980.

Cambridge University Press, Cambridge, pp.1-19, 1981,

http://dx.doi.org/10.1017/CBO9781139165860,

[5] Herman, B.: Integrity and Impartiality.

The Monist 66(2), 233-250, 1983,

http://dx.doi.org/10.5840/monist198366216,

[6] Blum, L.A.: Friendship, Altruism, and Morality.

Routledge \& Kegan Paul, UK, 1980,

http://dx.doi.org/10.2307/2960086,

[7] Stocker, M.: Schizophrenia of Modern Ethical Theories.

The Journal of Philosophy 73(14), 453-466, 1976,

http://dx.doi.org/10.2307/2025782,

[8] Foot, P.: Virtue and Vices.

In: Crisp, R.; Slote, M, eds.: Virtue Ethics.

Oxford University Press, New York, pp.163-178, 1997,

[9] Korsgaard, C.: From Duty and for the Sake of the Noble.

In: Engstrom, S.; Whiting, J. eds.: Aristotle, Kant, and the Stoics: Rethinking Happiness and Duty.

Cambridge University Press, Cambridge, pp.203-236, 1996,

[10] Hursthouse, R.: On Virtue Ethics.

Oxford University Press, Oxford, 1999,

[11] Oakley, J.: A Critique of Kantian Arguments against Emotions as Moral Motives.

History of Philosophy Quarterly 7(4), 441-459, 1990,

[12] Baron, M.W.: Kantian Ethics Almost Without Apology.

Cornell University Press, Ithaca, N.Y., 1995,

[13] Stohr, K.: Virtue ethics and Kant's cold-hearted benefactor.

Journal of Value Inquiry 36, 187-204, 2002,

http://dx.doi.org/10.1023/A:1016192117676,

[14] Tannenbaum, J.: Acting with Feeling from Duty.

Ethical Theory and Moral Practice 5(3), 321-337, 2002,

http://dx.doi.org/10.1023/A:1019627428116,

[15] Meyers, C.D.: The Virtue of Cold-Heartedness.

An International Journal for Philosophy in the Analytic Tradition 138(2), 233-244, 2008, http://dx.doi.org/10.1007/s11098-006-9034-3, 
[16] McMurray, W. Ashley.: Morality, the Good Life, and the Cold - Hearted Benefactor. Aporia 25(1), 11-20, 2015,

[17] Nagel, T.: The Possibility of Altruism. Clarendon Press, Oxford, 1970,

[18] Sherman, N.: Making a Necessity of Virtue: Aristotle and Kant on Virtue. Cambridge university Press, Cambridge, 1997. 